\begin{tabular}{|c|c|}
\hline 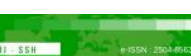 & Malaysian Journal of Social Sciences and Humanities (MJSSH) \\
\hline Malaysian Journal of & Volume 5, Issue 12, December 2020 \\
\hline (MJ-SSH) & e-ISSN : 2504-8562 \\
\hline & $\begin{array}{l}\text { Journal home page: } \\
\text { www.msocialsciences.com }\end{array}$ \\
\hline
\end{tabular}

\title{
Strategi Pemahaman Bacaan dalam Teks Bahasa Melayu Sebagai Bahasa Kedua dalam kalangan Murid Suku Kaum Rungus di Sabah
}

\author{
Nalmon Goyi ${ }^{1}$, Rohaidah Kamaruddin ${ }^{1}$, Hazlina Abdul Halim ${ }^{1}$, Sharil Nizam Sha'ri ${ }^{1}$ \\ ${ }^{1}$ Faculty of Modern Languages and Communication, Universiti Putra Malaysia (UPM)
}

Corrrespondence: Nalmon Goyi (nago201@yahoo.com)

\begin{abstract}
Abstrak
Kajian ini dijalankan terhadap murid suku kaum Rungus di Sekolah Menengah Kebangsaan Sikuati II, Kudat, Sabah. Tinjauan lapangan telah melibatkan enam puluh tiga orang murid dalam tingkatan empat. Mereka terdiri daripada dua kumpulan berdasarkan keputusan Pentaksiran Tingkatan Tiga. Kumpulan Pencapaian Rendah (KPR) terdiri daripada tiga puluh tujuh orang peserta sementara Kumpulan Pencapaian Tinggi (KPT) seramai dua puluh enam orang peserta. Penulis meneroka kekerapan penggunaan strategi kognitif dan meta kognitif peserta KPR dan KPT dalam pemahaman bacaan teks bahasa Melayu. Penulis memanipulasikan empat belas item soal selidik adaptasi daripada kajian Osuji (2017) dan menggunakan pemeringkatan min untuk semua item strategi. Bagi menentukan kekerapan penggunaan strategi kognitif dan meta kognitif oleh peserta kajian semasa menyempurnakan tugas pemahaman bacaan, penulis menetapkan titik interval 0.80 pada skala Likert 5 mata. Hasil kajian ini menunjukkan bahawa kedua-dua peserta kumpulan lebih kerap menggunakan strategi meta kognitif daripada strategi kognitif dalam pemahaman bacaan teks bahasa Melayu. Walau bagaimanapun, nilai min kekerapan penggunaan kedua-dua strategi dalam data KPT adalah lebih tinggi daripada KPR. Hasil kajian ini mempunyai implikasi positif terhadap pengajaran membaca dalam mata pelajaran Bahasa Melayu, khususnya dalam kalangan murid-murid peribumi Sabah yang bukan penutur jati bahasa Melayu.
\end{abstract}

Kata kunci: strategi kognitif, strategi meta kognitif, pemahaman bacaan, suku kaum Rungus, pelajar bahasa kedua

\section{Reading Comprehension Strategies in Malay Text as a Second Language among Rungus Tribe Students in Sabah}

\begin{abstract}
This study was conducted on students of the Rungus tribe at Sekolah Menengah Kebangsaan Sikuati II, Kudat, Sabah. The field survey has involved sixty-three students in form four. They consist of two groups based on the results of the Form Three Assessment. The Low Achievement Group (KPR) consists of thirty-seven participants, while the High Achievement Group (KPT) consists of twenty-six participants. The authors explore the participants' frequency of cognitive and metacognitive strategies in Malay language text reading comprehension. The authors manipulated fourteen questionnaire items adapted from Osuji's (2017) study and used mean ranking for all strategy items. To determine the participants' cognitive and metacognitive strategies while completing reading comprehension tasks, the
\end{abstract}


authors set an interval of 0.80 on a 5-point Likert scale. This study showed that both groups of participants often use more metacognitive strategies than cognitive strategies in Malay text reading comprehension. However, the mean value of the frequency used by both strategies in KPT data is higher than the KPR. These findings have positive implications for reading instruction in the Malay Language subject, especially among the Sabahan indigenous students who are not native speakers of Malay.

Keywords: cognitive strategy, meta-cognitive strategy, reading comprehension, Rungus tribe, second language learner

\section{Pengenalan}

Pemahaman bacaan dalam bahasa kedua ialah aktiviti yang kompleks dan dinamik. Hal ini disebabkan membaca melibatkan interaksi antara kecekapan bahasa dengan pembaca, ciri-ciri peribadi dan konteks luaran (Phakiti 2006: 54). Proses membaca melibatkan nyahkod simbol bercetak kepada bentuk fonologi bagi membolehkan pembaca dapat memahami makna teks. Pemahaman makna bukan hanya satu dimensi. Pembaca perlu mempunyai cukup pengetahuan kosa kata, tahu menyusun ayat dan tahu memproses maklumat daripada petikan berdasarkan pengetahuan sedia ada (Koda 2007: 2). Selain pengetahuan linguistik, pembaca perlu menggunakan pengalaman hidupnya untuk memahami teks. Proses membaca juga menghendaki pembaca menggunakan sejumlah mod operasi tertentu yang dikenali sebagai "strategi membaca" untuk memahami kandungan teks (Kern 1989: 135). Menurut Zhang \& Wu (2009: 49), pembaca menggunakan lebih banyak strategi membaca apabila teks semakin sukar. Pembaca juga menggunakan satu set strategi membaca untuk memahami teks tertulis. Pembaca sedemikian ialah pembaca yang aktif. Dengan kata lain, pembaca mempunyai tujuan yang jelas dalam fikiran, menyedari akan penggunaan satu set strategi membaca untuk mengatur dan meningkatkan pemahaman bacaan. Strategi membaca memberi kesan positif dalam pembelajaran bahasa pelajar bahasa kedua. Menurut Bimmel et al. (2001:510), strategi membaca didefinisikan sebagai tindakan minda yang dirancang untuk mencapai tujuan membaca. Strategi membaca ditafsirkan sebagai operasi minda yang dipilih dan diterapkan oleh pembaca untuk memahami apa yang mereka baca (Abbott 2006: 637). Strategi membaca memberi sumbangan positif kepada proses pembelajaran sekiranya digunakan dalam konteks yang betul. Terdapat dua kategori strategi pemahaman bacaan. Kategori pertama ialah strategi penggunaan, dengan penekanan pada sifat sedar dan sengaja pembaca. Pembaca menggunakan strategi penggunaan untuk meningkatkan prestasi pemahaman bacaan. McNeil (2010: 885) mengukuhkan pandangan tersebut bahawa strategi pemahaman bacaan ialah tindakan sedar pembaca semasa pembaikan pemahaman (strategi kognitif) atau tindakan yang disengajakan untuk memantau usaha pembaikan pemahaman (strategi meta kognitif). Pembaca menggunakan strategi kognitif dan meta kognitif sebagai dua strategi asas semasa membaca (Yau 2013). Perenggan seterusnya menjelaskan konstruk strategi kognitif dan strategi meta kognitif.

\section{Strategi Pemahaman Bacaan}

Strategi kognitif didefinisikan sebagai tindakan yang disengajakan oleh pembaca apabila masalah pemahaman timbul. Strategi kognitif digunakan untuk menggiatkan proses kognitif seperti menggaris beberapa bahagian teks, membaca kembali sebahagian atau seluruh teks untuk meningkatkan pemahaman, atau mengurangkan kecepatan membaca bila pemahaman terganggu (Sheorey \& Mokhtari 2001: 431). Selain menggambarkan strategi kognitif (ringkasan, SK) sebagai tindakan secara fizikal, SK juga berkaitan dengan proses minda. Oxford (2011: 44) lebih suka menyebut SK sebagai pemprosesan yang beroperasi pada tiga peringkat, iaitu tahap pengetahuan deklarasi, asosiasi, dan prosedur. Tahap deklarasi ialah tahap sedar, bersungguh-sungguh, berhenti, dan tidak lazim. Menurut Yau (2013: 176), SK ialah platform yang membolehkan pembaca menangani maklumat baharu. Pada tahap asosiasi, pembaca mempraktikkan perolehan maklumat baharu daripada tugasan. Pada tahap prosedur, maklumat baharu ditukar secara serta-merta di luar kesedaran pembaca, dan dapat dikerah dengan sedikit usaha. Bimmel et al. (2001: 511) mengenal pasti tiga kumpulan SK yang digunakan oleh pembaca. Strategi kumpulan 1 melibatkan 'penggunaan pengetahuan linguistik dan bukan linguistik, iaitu meramal, 
membuat kesimpulan dan menghuraikan. Strategi kumpulan 2 melibatkan penggunaan elemen teks dengan maklumat yang bernilai tinggi, iaitu mencari pecahan utama, membuat catatan, menyoal, dan meringkaskan. Strategi kumpulan 3 melibatkan penggunaan elemen penunjuk struktur dalam teks, iaitu menghubungkan kata atau frasa. Phakiti (2003: 651) melihat SK sebagai perkaitan langsung dengan bahasa sasaran dan pengetahuan dunia pembaca. Dengan itu, pembaca boleh membina makna daripada teks termasuk meramal, menterjemah, meringkaskan, menghubungkan pengetahuan atau pengalaman lampau, menerapkan peraturan tatabahasa dan meneka makna. Sebaliknya, strategi meta kognitif terdiri daripada merancang, memantau dan menilai proses pembelajaran atau pemahaman bacaan. Bagi Phakiti (2003: 699), konsep strategi meta kognitif (ringkasan, SMK) melibatkan usaha merancang, memantau dan menilai proses pembelajaran sesuatu tugasan. Dalam model Phakiti, merancang dijelaskan sebagai pra tinjauan organisasi tugasan yang terdiri daripada persiapan, pengenalpastian masalah, penetapan pilihan, pengurusan dan keutamaan matlamat. Memantau dan menilai dijelaskan sebagai memeriksa, mengesahkan atau membetulkan prestasi semasa membaca atau setelah selesai membaca mengikut standard ulang semak, penilaian prestasi dan pemantauan masalah.

Artikel ini melaporkan hasil kajian yang berkaitan dengan objektif kajian dan persoalan kajian yang berikut:

\section{Objektif Kajian}

Mengenal pasti kekerapan penggunaan strategi kognitif dan strategi meta kognitif dalam pemahaman bacaan teks bahasa Melayu dua kumpulan peserta suku kaum Rungus.

\section{Persoalan Kajian}

Apakah strategi pemahaman bacaan yang lebih kerap digunakan oleh murid suku kaum Rungus semasa menyempurnakan tugasan dalam bahasa Melayu?

\section{Pernyataan Masalah}

Kajian tentang strategi kognitif dan meta kognitif dalam pemahaman bacaan pelajar suku kaum Rungus belum pernah dilakukan di daerah Kudat, Sabah. Kajian ini perlu dilakukan agar penelitian kesan strategi bacaan terhadap prestasi pemahaman teks oleh murid suku kaum Rungus dikenal pasti kerana mereka ialah masyarakat majoriti di lokasi kajian. Tanpa penyelidikan seperti ini, tidak ada laporan data yang tepat sama ada pelajar suku kaum Rungus mengaplikasikan strategi kognitif dan meta kognitif dalam pemahaman bacaan teks bahasa Melayu. Perkara ini menyukarkan guru-guru bahasa untuk menangani kelemahan dalam pemahaman teks oleh murid suku kaum Rungus yang menggunakan bahasa Melayu sebagai bahasa kedua. Berdasarkan analisis keputusan Bahasa Melayu dalam Pentaksiran Tingkatan Tiga (PT3) tahun 2017, didapati pencapaian mata pelajaran Bahasa Melayu di daerah Kudat, Sabah perlu ditingkatkan lagi. Berikut ialah statistik yang menunjukkan pencapaian murid dalam mata pelajaran Bahasa Melayu PT3 di dua buah sekolah di daerah Kudat yang majoriti muridnya ialah suku kaum Rungus. Jadual 1 memaparkan pencapaian murid dalam mata pelajaran Bahasa Melayu PT3 pada tahun 2017.

Berdasarkan Jadual 1, bilangan murid yang memperoleh gred rendah, iaitu skor D, E dan F adalah lebih ramai berbanding murid yang memperoleh sekurang-kurang gred C Bahasa Melayu dalam PT3. Perkara ini menunjukkan bahawa murid di daerah ini belum dapat menguasai sepenuhnya bahasa Melayu dengan baik dan berkesan. Bagi memahami dengan jelas tentang masalah ini, satu penyelidikan secara berfokus perlu dilaksanakan. Sebahagian besar murid di daerah ini, khususnya di dua buah sekolah (A dan B) terdiri daripada suku kaum Rungus. Oleh sebab itu, penulis berpendapat bahawa suatu penyelidikan tentang kesan strategi bacaan terhadap prestasi pemahaman teks dalam kalangan murid suku kaum Rungus perlu dilaksanakan sebagai langkah awal untuk menangani masalah tidak cemerlang dalam mata pelajaran Bahasa Melayu. 
Jadual 1: Pencapaian Pelajar dalam Bahasa Melayu PT3

Tahun 2017

\begin{tabular}{ccc}
\hline Gred & Sekolah Menengah A & Sekolah Menengah B \\
\hline A & 26 & 14 \\
B & 28 & 31 \\
C & 28 & 27 \\
D & 15 & 27 \\
E & 30 & 19 \\
F & 54 & 36 \\
Jumlah Hadir & 181 & 154 \\
Jumlah Calon & 189 & 154 \\
\hline
\end{tabular}

Sumber: Unit Peperiksaan SMK Sikuati dan SMK Sikuati II, Februari, 2018

Proses membaca dalam bahasa kedua terdiri daripada kluster strategi kognitif dan meta kognitif yang berinteraksi antara satu sama lain (Macaro 2006: 330). Proses membaca dalam bahasa kedua bertujuan untuk membolehkan teks dalam bahasa kedua dapat difahami dengan bantuan strategi kognitif dan meta kognitif sebagai unsur proses. Walaupun kajian menunjukkan bahawa penggunaan strategi kognitif oleh pembaca semasa proses membaca cenderung bergantung kepada faktor-faktor tertentu, satu faktor yang boleh mempengaruhi pemprosesan kognitif dan meta kognitif dalam pemahaman bacaan yang kurang mendapat perhatian ialah aras pencapaian mata pelajaran Bahasa Melayu murid. Bagaimana aras pencapaian mata pelajaran Bahasa Melayu murid bahasa kedua dapat mempengaruhi pemprosesan kognitif dan meta kognitif semasa pemahaman bacaan teks bahasa Melayu masih belum banyak diketahui. Walaupun terdapat penemuan tentang pengaruh penguasaan bahasa kedua terhadap proses kognitif dan meta kognitif, data lebih bersifat konseptual tanpa usaha untuk mengukur pemahaman membaca secara khusus.

\section{Kepentingan Kajian}

Penemuan dalam kajian ini boleh menyumbang kepada perubahan cara guru di Malaysia mengajar pemahaman bacaan dan faedah strategi kognitif dan strategi meta kognitif terhadap murid kerana dapat memudahkan pemahaman bacaan. Dari sudut pandangan teori, penggunaan strategi kognitif dan meta kognitif menyegarkan perkaitan sumber pengetahuan perbendaharaan kata bahasa kedua dan pengalaman sedia ada murid. Oleh itu, strategi pemahaman bacaan memberi peluang kepada murid untuk meningkatkan pencapaian dalam mata pelajaran Bahasa Melayu. Hasil akhir kajian ini diharapkan dapat membantu guru-guru Bahasa Melayu untuk memahami dengan lebih jelas dan luas tentang fenomena pemahaman bacaan dalam kalangan pelajar suku kaum Rungus serta mengaplikasikan strategi kognitif dan meta kognitif. Berdasarkan kajian lepas, pencapaian keseluruhan murid sekolah menengah yang dikaji meningkat apabila kemahiran literasi, iaitu membaca dan mengarang diberi keutamaan dalam kurikulum sekolah.

Sebagaimana yang dinyatakan sebelum ini, majoriti murid di daerah Kudat terdiri daripada suku kaum Rungus. Murid daripada suku kaum Rungus ini memberi sumbangan yang besar ke atas prestasi keseluruhan sesebuah sekolah bukan sahaja di daerah Kudat, malah di seluruh bahagian utara Sabah, iaitu merangkumi daerah Matunggong, Bengkoka dan Pitas kerana murid daripada suku kaum Rungus inilah yang dominan di bahagian utara Sabah dari segi populasi. Jika prestasi murid suku kaum Rungus meningkat, maka akan memberikan kesan langsung yang baik kepada prestasi keseluruhan sesebuah sekolah yang memberi imej yang baik kepada sesebuah sekolah. Maklumat daripada hasil kajian tentang strategi kognitif dan meta kognitif dalam pemahaman bacaan pelajar suku kaum Rungus dapat dimanfaatkan oleh guru bahasa bagi menyediakan strategi pengajaran dan pembelajaran yang lebih berkesan kepada murid bahasa kedua. 


\section{Sorotan Literatur}

Kutluturk \& Yumru (2017) telah menyelidik kesan strategi kognitif dan meta kognitif semasa pelajar membaca teks yang ditulis dalam bahasa Inggeris. Kajian ini dijalankan di Pusat Pengajian Bahasa Asing di Malatya, Turki. Peserta terdiri daripada 27 orang pelajar yang berusia 18 hingga 21 tahun. Pengkaji mendapati pelajar menggunakan strategi meta kognitif untuk merancang dan memantau proses pemahaman mereka, menghuraikan pengetahuan sedia ada, menyelesaikan masalah tugasan dan menilai cara menyelesaikan tugasan. Penemuan yang paling jelas daripada kajian ini menunjukkan setelah menjalani latihan menggunakan strategi meta kognitif para pelajar dapat menerapkan strategi itu untuk pemahaman bacaan berbagai jenis teks (Kutluturk \& Yumru 2017: 14). Dapatan kajian ini selaras dengan hasil kajian yang menyokong latihan strategi meta kognitif membantu para siswa mengatur dan mengendalikan kemajuan pembelajaran (Williams et al. 2015: 124).

Elekaei, Tabrizi \& Chalak (2020) pernah menyelidik kesan strategi kognitif dan meta kognitif terhadap peningkatan perbendaharaan kata peserta dalam konteks e-pembelajaran. Seramai 180 orang peserta mengambil bahagian dalam kajian ini. Pengkaji mendapati bahawa tahap peningkatan dan pengekalan perbendaharaan kata dipengaruhi strategi kognitif. Strategi meta kognitif tidak mempunyai pengaruh yang besar pada tahap peningkatan dan pengekalan perbendaharaan kata. Pengkaji melaporkan bahawa penggunaan strategi kognitif mempermudah pembelajaran bahasa kedua dengan kaedah terjemahan bahasa pertama. Selain itu, tahap motivasi dan sikap pelajar mempengaruhi strategi yang dipilih oleh pelajar (Elekaei, Tabrizi \& Chalak 2020: 113). Hasil kajian ini menyokong kajian Ashton-Hay \& Brookes (2011) yang melaporkan bahawa strategi pembelajaran bahasa mempermudah pembelajaran bahasa. Penemuan kajian ini juga selaras dengan kajian Zarei \& Elekaei (2012). Mereka mendapati bahawa tahap motivasi dan sikap sangat mempengaruhi strategi pilihan pelajar.

Latifa (2017) telah mengusahakan kajian tentang strategi meta kognitif dan strategi Kognitif dalam pemahaman bacaan. Peserta terdiri daripada 30 orang pelajar sekolah menengah di Bandung. Instrumen yang digunakan dalam kajian ini diadaptasi daripada Maftoon \& Tasnimi (2014). Hasil tugasan yang menggunakan strategi meta kognitif menunjukkan pelajar cenderung mengabaikan proses menyusun dan mengubah teks, iaitu aktiviti pertama yang perlu disempurnakan dalam strategi meta kognitif. Sebilangan daripada pelajar tidak biasa membuat perancangan sebelum melakukan tugasan pemahaman bacaan. Oleh sebab itu, mereka menghadapi masalah menguruskan masa menyelesaikan tugasan. Sebaliknya, pelajar dapat menerapkan strategi kognitif dengan lebih baik. Mereka mempunyai lebih banyak inisiatif, terutama dalam mengulang kaji dan menghafal. Mereka juga fokus untuk mencari maklumat tentang kata-kata yang tidak jelas dengan meneka, bertanya kepada rakan atau guru dan menggunakan kamus (Latifa 2017: 271).

Ahmed (2020) telah meneroka kesedaran penggunaan strategi kognitif dan meta kognitif dalam pemahaman bacaan oleh pelajar diploma tahun pertama di Oman yang berjumlah 375 orang. Pengkaji mendapati bahawa pelajar paling menyukai strategi kognitif. Dapatan kajian ini menunjukkan bahawa para peserta mempunyai kesedaran menggunakan strategi kognitif lebih kerap daripada strategi meta kognitif. Dapatan ini selaras dengan kajian Commander et al. (2016) bahawa strategi kognitif ialah kategori strategi yang pelajar paling suka. Selain strategi kognitif, pelajar menilai strategi meta kognitif dengan penggunaan sederhana. Pelajar tidak memilih strategi meta kognitif kerana dianggap mencabar. Cara penggunaan strategi meta kognitif seperti menganalisis dan menilai apa yang dibaca serta mengesahkan ramalan memerlukan latihan tambahan (Ahmed 2020: 302).

Tabatabaei et al. (2017) telah mengenal pasti kesan strategi kognitif dan meta kognitif dalam motivasi pembelajaran bahasa 46 orang pelajar. Dapatan kajian ini menunjukkan bahawa pelajar berkemahiran tahap rendah memilih strategi kognitif. Strategi kognitif digunakan untuk mengurus pembelajaran, mengingat dan berfikir. Matlamat strategi kognitif termasuk memahami data dan pembelajaran yang bermakna dapat direalisasikan melalui pemprosesan maklumat (Tabatabaei et al. 2017: 243). Hasil kajian ini menggambarkan bahawa motivasi mempengaruhi strategi meta kognitif pelajar berkemahiran tahap tinggi. Terdapat hubungan positif yang signifikan antara kesedaran meta kognitif dan prestasi pelajar. Pelajar yang berjaya ialah pelajar yang memantau kemahiran belajar mereka melalui penggunaan strategi 
meta kognitif. Penggunaan strategi meta kognitif dapat memajukan prestasi pelajar. Pelajar yang tidak menggunakan strategi meta kognitif dikatakan mempunyai prestasi tahap rendah.

\section{Metod Kajian}

Kajian tinjauan ini dijalankan di Sekolah Menengah Kebangsaan Sikuati II, Kudat, Sabah. Seramai enam puluh tiga orang murid suku kaum Rungus dari lima buah kelas tingkatan empat terlibat sebagai peserta kajian. Mereka dikategorikan dalam dua kumpulan mengikut keputusan Pentaksiran Tingkatan 3 (PT3). Kumpulan Pencapaian Rendah (KPR) yang berjumlah tiga puluh tujuh orang peserta ialah murid yang mendapat skor di bawah 40 peratus. Seramai 26 orang peserta layak berada dalam Kumpulan Pencapaian Tinggi (KPT). Mereka ialah murid yang memperoleh skor 40 peratus dan ke atas. Semua peserta kajian masih menggunakan bahasa Rungus sebagai bahasa pertama dan bahasa Melayu sebagai bahasa kedua.

Jadual dan rajah dalam artikel ini mengemukakan statistik deskriptif respons peserta terhadap item soal selidik. Nilai min setiap item soal selidik diperoleh berdasarkan skala Likert 5 mata. Walaupun terdapat kontroversi tentang kesesuaian analisis data berdasarkan skala Likert, pendekatan ini diterima bukan hanya kerana popularitinya dalam penyelidikan malahan skala ordinal dapat dikurangkan menjadi data interval apabila jumlah item banyak (Carifio \& Perla 2008; Norman 2010). Penulis meneroka penggunaan strategi kognitif dan meta kognitif peserta KPR dan KPT dalam pemahaman bacaan teks bahasa Melayu. Terdapat empat belas strategi membaca yang disenaraikan dalam soal selidik yang diadaptasi daripada kajian Osuji (2017). Penulis menggunakan pemeringkatan min (mean rating) bagi semua item strategi yang dianalisis. Bagi menentukan kekerapan penggunaan strategi kognitif dan meta kognitif oleh peserta semasa menyempurnakan tugas pemahaman bacaan, penulis menetapkan titik interval 0.80 mengikut skala Likert 5 mata (Osuji 2017: 62 ). Penetapan dengan cara demikian membolehkan penulis menentukan tahap penggunaan strategi kognitif dan strategi meta kognitif. Berikut ialah tafsiran tahap penggunaan kedua-dua strategi tersebut dalam pemahaman bacaan.

i. Skor min $1.00-1.80$ menunjukkan bahawa peserta tidak pernah menggunakan strategi tertentu (tahap sangat rendah)

ii. Skor min $1.81-2.60$ menunjukkan bahawa peserta kadangkala menggunakan satu strategi tertentu (tahap penggunaan yang rendah)

iii. Skor min 2.61-3.40 menunjukkan bahawa peserta kerap kali menggunakan satu strategi tertentu (tahap penggunaan yang sederhana)

iv. Skor min $3.41-4.20$ menunjukkan bahawa peserta biasanya menggunakan satu strategi tertentu (tahap penggunaan yang tinggi)

v. Skor min $4.21-5.00$ menunjukkan bahawa peserta selalu menggunakan satu strategi tertentu bila mereka membaca (tahap penggunaan sangat tinggi).

\section{Hasil Kajian}

Matlamat kajian ini adalah untuk mengenal pasti strategi yang digunakan oleh peserta suku kaum Rungus semasa menyempurnakan tugasan pemahaman bacaan teks bahasa Melayu. Rajah 1 memaparkan nilai min kekerapan penggunaan lima item strategi kognitif dalam pemahaman bacaan Kumpulan Pencapaian Rendah (KPR) dan Kumpulan Pencapaian Tinggi (KPT). Berdasarkan data KPR, nilai min 2.14, 2.65 dan 2.57 penggunaan strategi kognitif adalah pada tahap rendah. Nilai min 3.3 bermaksud penggunaan strategi kognitif berada pada tahap sederhana. Hanya satu nilai min item strategi kognitif pada tahap sangat tinggi, iaitu 4.22. Tahap penggunaan strategi kognitif dalam pemahaman bacaan KPT adalah lebih tinggi daripada KPR kerana penulis tidak mendapati sebarang nilai min yang ditafsirkan sebagai rendah mahupun sederhana dalam data KPT. Nilai min 4.08, 3.69 dan 4.12 menunjukkan penggunaan strategi kognitif pada tahap tinggi sementara 4.35 dan 4.23 pada tahap sangat tinggi. 
DOI: https://doi.org/10.47405/mjssh.v5i12.579

Rajah 1: Min Strategi Kognitif dalam Pemahaman Bacaan Peserta Dua Kumpulan

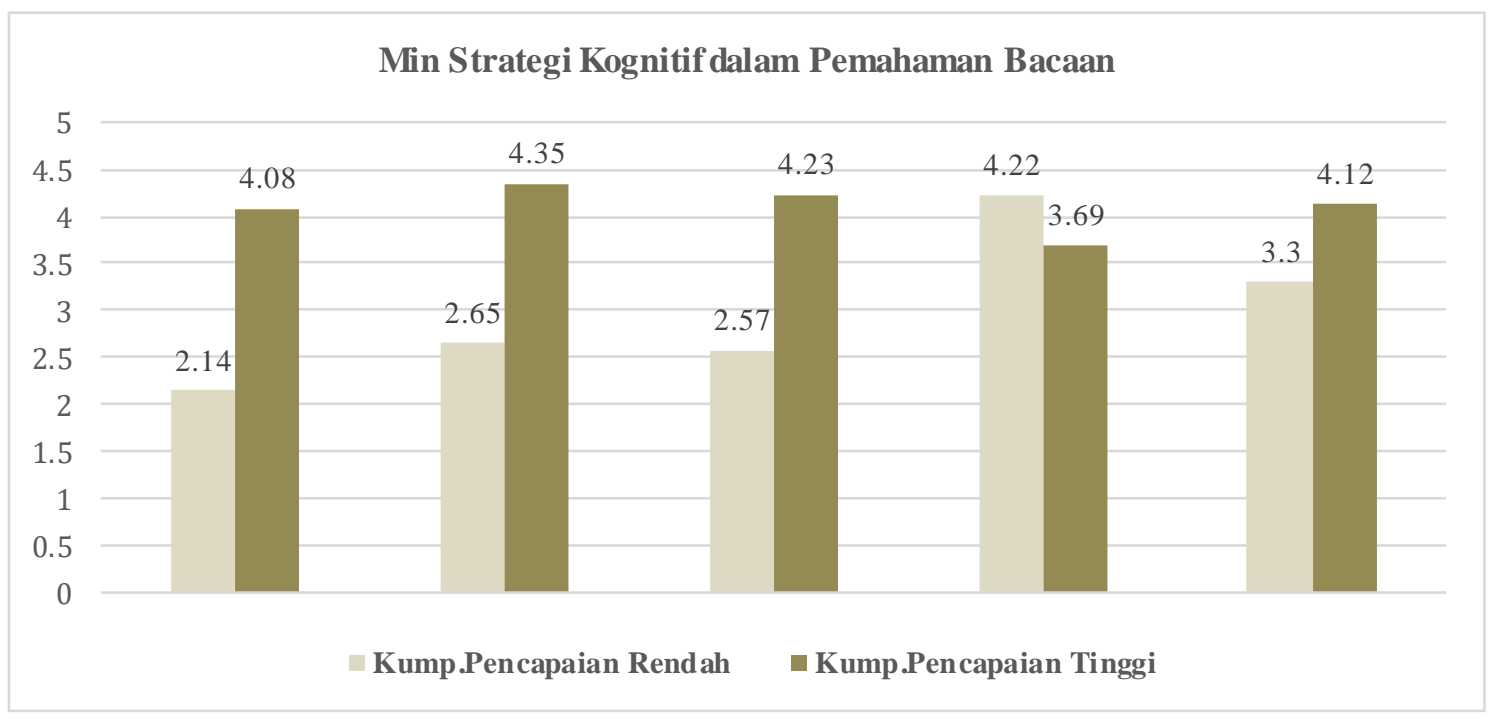

Seterusnya, Rajah 2 menerangkan nilai min kekerapan penggunaan sembilan item strategi meta kognitif dalam pemahaman bacaan Kumpulan Pencapaian Rendah (KPR) dan Kumpulan Pencapaian Tinggi (KPT).

Rajah 2: Min Strategi Meta Kognitif dalam Pemahaman Bacaan Peserta Dua Kumpulan

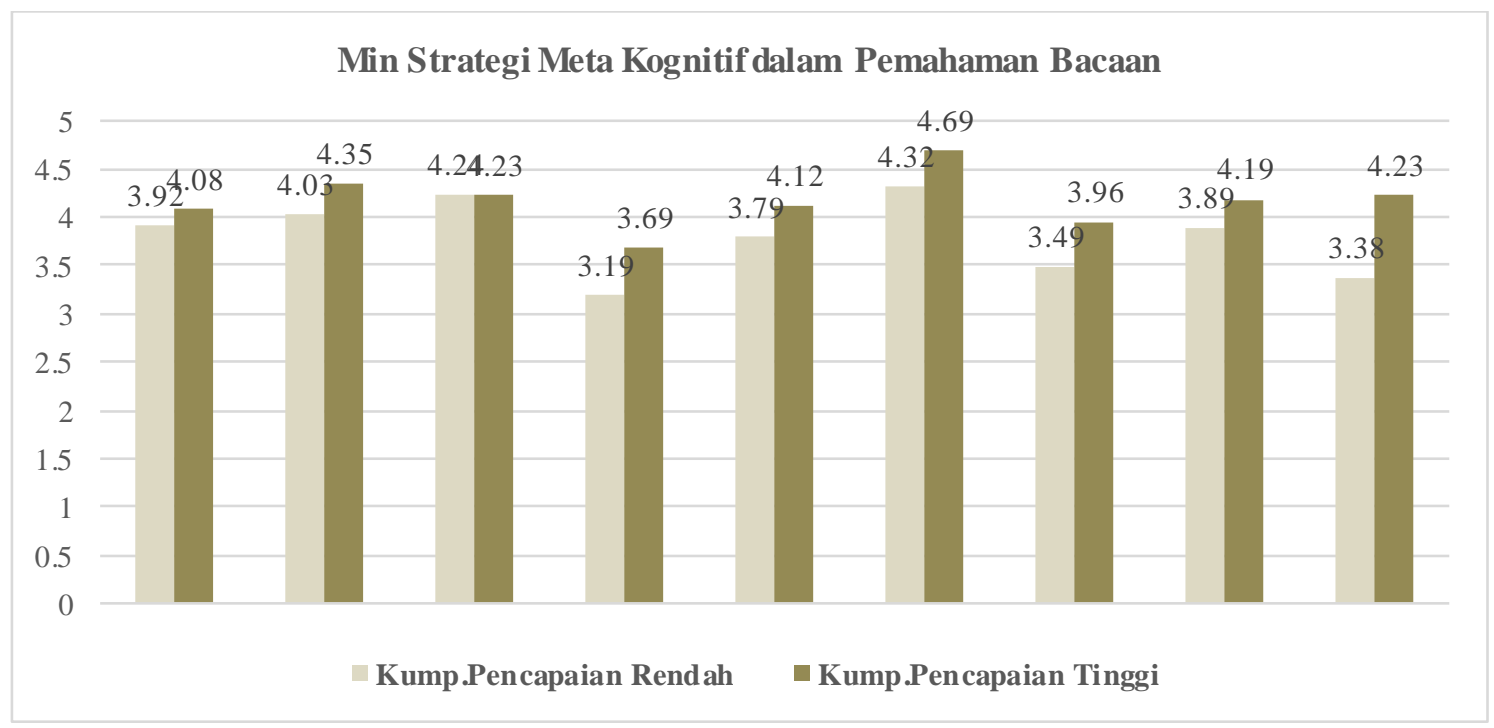

Dalam data KPR terdapat dua nilai min pemahaman bacaan pada tahap penggunaan sederhana, iaitu 3.19 dan 3.38. Penggunaan strategi meta kognitif dalam pemahaman bacaan pada tahap tinggi yang paling kerap adalah sebanyak lima, iaitu 3.92, 4.03, 3.79, 3.49 dan 3.89. Terdapat dua strategi meta kognitif pada tahap penggunaan sangat tinggi dengan nilai 4. 24 dan 4.32 diperoleh peserta KPR. Dalam data KPT tidak terdapat nilai min pemahaman bacaan pada tahap penggunaan sederhana seperti dalam data KPR. Penggunaan strategi meta kognitif dalam pemahaman bacaan pada tahap tinggi yang paling kerap adalah sebanyak lima, iaitu 4.08, 3.69, 4.12, 3.96 dan 4.19. Terdapat empat strategi meta kognitif pada tahap penggunaan sangat tinggi dengan nilai 4. 35, 4.23, 4.69 dan 4.32 diperoleh peserta KPT. Penelitian nilai min berdasarkan data dalam Rajah 2 menunjukkan KPT lebih kerap menggunakan strategi meta kognitif dalam pemahaman bacaan teks bahasa Melayu. 
DOI: https://doi.org/10.47405/mjssh.v5i12.579

Jadual 2 menunjukkan perincian analisis soalan bagi 14 item strategi, min kekerapan dan tahap penggunaan strategi kognitif dan meta kognitif pemahaman bacaan peserta Kumpulan Pencapaian Rendah (KPR).

Jadual 2: Penggunaan Strategi dalam Pemahaman Bacaan Peserta KPR

\begin{tabular}{|c|c|c|c|}
\hline Item & Soalan Strategi Kognitif & Min & $\begin{array}{l}\text { Tahap } \\
\text { Penggunaan } \\
\text { Strategi }\end{array}$ \\
\hline 1 & $\begin{array}{l}\text { Saya menterjemahkan teks bacaan dan tugasan ke } \\
\text { dalam bahasa Rungus untuk meningkatkan } \\
\text { pemahaman saya. }\end{array}$ & 2.14 & Rendah \\
\hline 2 & $\begin{array}{l}\text { Saya cuba memahami teks dan soalan tanpa } \\
\text { menghiraukan pengetahuan perbendaharaan kata } \\
\text { saya. }\end{array}$ & 2.65 & Sederhana \\
\hline 3 & $\begin{array}{l}\text { Saya cuba mencari topik dan idea utama petikan } \\
\text { tanpa membaca secara terperinci. }\end{array}$ & 2.57 & Rendah \\
\hline 4 & $\begin{array}{l}\text { Saya membaca teks dan soalan beberapa kali } \\
\text { untuk lebih memahaminya. }\end{array}$ & 4.22 & $\begin{array}{l}\text { Sangat } \\
\text { Tinggi }\end{array}$ \\
\hline 5 & $\begin{array}{l}\text { Saya menggunakan pengetahuan terdahulu untuk } \\
\text { membantu saya memahami teks. }\end{array}$ & 3.30 & Sederhana \\
\hline Item & Soalan Strategi Meta Kognitif & & \\
\hline 6 & $\begin{array}{l}\text { Saya sedar akan apa dan bagaimana saya } \\
\text { menjawab ujian. }\end{array}$ & 3.92 & Tinggi \\
\hline 7 & $\begin{array}{l}\text { Saya menyemak jawapan saya semasa sedang } \\
\text { menjalani ujian. }\end{array}$ & 4.03 & Tinggi \\
\hline 8 & $\begin{array}{l}\text { Saya membetulkan kesilapan dengan segera } \\
\text { apabila ditemui. }\end{array}$ & 4.24 & $\begin{array}{l}\text { Sangat } \\
\text { Tinggi }\end{array}$ \\
\hline 9 & $\begin{array}{l}\text { Saya menentukan apa soalan ujian kehendaki } \\
\text { saya lakukan. }\end{array}$ & 3.19 & Sederhana \\
\hline 10 & $\begin{array}{l}\text { Saya sedar akan keperluan untuk merancang } \\
\text { tindakan. }\end{array}$ & 3.76 & Tinggi \\
\hline 11 & $\begin{array}{l}\text { Saya cuba memahami soalan-soalan secukupnya } \\
\text { sebelum cuba menjawabnya. }\end{array}$ & 4.32 & $\begin{array}{l}\text { Sangat } \\
\text { Tinggi }\end{array}$ \\
\hline 12 & $\begin{array}{l}\text { Saya sedar ada strategi terpilih yang dapat } \\
\text { membantu saya untuk melengkapkan soalan ujian } \\
\text { sebelum menyelesaikannya. }\end{array}$ & 3.49 & Tinggi \\
\hline 13 & $\begin{array}{l}\text { Saya memeriksa ketepatan jawapan saya semasa } \\
\text { saya sedang menjalani ujian. }\end{array}$ & 3.89 & Tinggi \\
\hline 14 & $\begin{array}{l}\text { Saya mengenal pasti maklumat yang relevan } \\
\text { dalam teks untuk membantu saya memahami teks } \\
\text { dan menjawab soalan. }\end{array}$ & 3.38 & Sederhana \\
\hline
\end{tabular}

Jadual 2 memaparkan tahap penggunaan strategi kognitif (Soalan 1-5) dan strategi meta kognitif (Soalan 6-14) dalam pemahaman bacaan teks bahasa Melayu oleh peserta suku kaum Rungus dalam Kumpulan Pencapaian Rendah (KPR). Soalan 1, 'saya menterjemahkan teks bacaan dan tugasan ke dalam bahasa Rungus untuk meningkatkan pemahaman saya' memperoleh skor min 2.14. Data ini menunjukkan bahawa strategi kognitif ini digunakan pada tahap rendah. Soalan 2, 'saya cuba memahami teks dan soalan tanpa menghiraukan pengetahuan perbendaharaan kata saya' memperoleh skor min 2.65. Hal ini bermakna strategi kognitif ini digunakan pada tahap sederhana. Soalan 3, 'saya cuba mencari topik dan idea utama petikan tanpa membaca secara terperinci' memperoleh skor min 2.57. Strategi kognitif ini digunakan pada tahap rendah. Soalan 4 'saya membaca teks dan soalan beberapa kali untuk lebih memahaminya' memperoleh skor min 4.22. Jelas bahawa strategi kognitif ini digunakan pada tahap sangat tinggi. Soalan 5, 'saya menggunakan pengetahuan terdahulu untuk membantu memahami teks' 
memperoleh skor min 3.30. Penulis mendapati bahawa strategi kognitif ini digunakan pada tahap sederhana.

Seterusnya, soalan 6, 'saya sedar akan apa dan bagaimana saya menjawab ujian' memperoleh skor min 3.92. Data ini menunjukkan bahawa strategi meta kognitif ini digunakan pada tahap tinggi. Soalan 7 , 'saya menyemak jawapan saya semasa sedang menjalani ujian' memperoleh skor min 4.03. Jelas bahawa strategi meta kognitif ini digunakan pada tahap tinggi oleh peserta Kumpulan Pencapaian Rendah (KPR). Soalan 8, "saya membetulkan kesilapan dengan segera apabila ditemui memperoleh skor min 4.24. Strategi meta kognitif ini digunakan pada tahap sangat tinggi. Soalan 9, 'saya menentukan apa soalan ujian kehendaki saya lakukan memperoleh skor min 3.19, iaitu strategi meta kognitif ini digunakan pada tahap yang sederhana. Soalan 10, 'saya sedar akan keperluan untuk merancang tindakan' memperoleh skor min 3.76. Data ini menunjukkan bahawa strategi meta kognitif ini digunakan pada tahap tinggi. Soalan 11, 'saya cuba memahami soalan-soalan secukupnya sebelum cuba menjawabnya' memperoleh skor min 4.32. Strategi meta kognitif ini digunakan pada tahap sangat tinggi. Soalan 12, 'saya sedar ada strategi terpilih yang dapat membantu saya untuk melengkapkan soalan ujian sebelum menyelesaikannya' memperoleh skor min 3.49, iaitu pada tahap tinggi. Soalan 13, 'saya memeriksa ketepatan jawapan saya semasa saya sedang menjalani ujian' memperoleh skor min 3.89. Strategi meta kognitif ini digunakan pada tahap tinggi. Soalan 14 , 'saya mengenal pasti maklumat yang relevan dalam teks untuk membantu saya memahami teks dan menjawab soalan' memperoleh skor min 3.38. Penulis mendapati bahawa strategi meta kognitif ini digunakan pada tahap sederhana.

Berdasarkan data tahap penggunaan strategi kognitif pada Jadual 1, dua item strategi kognitif memperoleh respons tahap rendah, dua sederhana, dan satu pada tahap sangat tinggi. Bagi strategi meta kognitif, tidak ada item yang memperoleh respons rendah. Tahap sederhana mendapat dua respons, tahap tinggi memperoleh lima respons sementara dua respons adalah pada tahap sangat tinggi. Berdasarkan perbandingan data ini, penulis menyimpulkan bahawa peserta Kumpulan Pencapaian Rendah (KPR) lebih cenderung menggunakan strategi meta kognitif dalam tugasan pemahaman bacaan teks bahasa Melayu.

Jadual 3 mengemukakan tahap penggunaan strategi kognitif (Soalan 1-5) dan strategi meta kognitif (Soalan 6-14) dalam pemahaman bacaan teks bahasa Melayu oleh peserta suku kaum Rungus dalam Kumpulan Pencapaian Tinggi (KPT).

Jadual 3: Penggunaan Strategi dalam Pemahaman Bacaan Peserta KPT

\begin{tabular}{|c|c|c|c|}
\hline Item & Soalan Strategi Kognitif & Min & $\begin{array}{c}\text { Tahap } \\
\text { Penggunaan } \\
\text { Strategi } \\
\end{array}$ \\
\hline 1 & $\begin{array}{l}\text { Saya menterjemahkan teks bacaan dan tugasan ke } \\
\text { dalam bahasa Rungus untuk meningkatkan } \\
\text { pemahaman saya. }\end{array}$ & 4.08 & Tinggi \\
\hline 2 & $\begin{array}{l}\text { Saya cuba memahami teks dan soalan tanpa } \\
\text { menghiraukan pengetahuan perbendaharaan kata } \\
\text { saya. }\end{array}$ & 4.35 & $\begin{array}{l}\text { Sangat } \\
\text { Tinggi }\end{array}$ \\
\hline 3 & $\begin{array}{l}\text { Saya cuba mencari topik dan idea utama petikan } \\
\text { tanpa membaca secara terperinci. }\end{array}$ & 4.23 & $\begin{array}{l}\text { Sangat } \\
\text { Tinggi }\end{array}$ \\
\hline 4 & $\begin{array}{l}\text { Saya membaca teks dan soalan beberapa kali } \\
\text { untuk lebih memahaminya. }\end{array}$ & 3.69 & Tinggi \\
\hline 5 & $\begin{array}{l}\text { Saya menggunakan pengetahuan terdahulu untuk } \\
\text { membantu saya memahami teks. }\end{array}$ & 4.12 & Tinggi \\
\hline Item & Soalan Strategi Meta Kognitif & & \\
\hline 6 & $\begin{array}{l}\text { Saya sedar akan apa dan bagaimana saya } \\
\text { menjawab ujian. }\end{array}$ & 4.08 & Tinggi \\
\hline
\end{tabular}


DOI: https://doi.org/10.47405/mjssh.v5i12.579

$7 \quad$ Saya menyemak jawapan saya semasa sedang menjalani ujian.

8 Saya membetulkan kesilapan dengan segera apabila ditemui.

4.35 Sangat

Saya menentukan apa soalan ujian kehendaki saya lakukan.

10 Saya sedar akan keperluan untuk merancang tindakan.

Tinggi

Sangat

Tinggi

Tinggi

4.12

Tinggi

11 Saya cuba memahami soalan-soalan secukupnya sebelum cuba menjawabnya.

4.69 Sangat

Tinggi

12 Saya sedar ada strategi terpilih yang dapat membantu saya untuk melengkapkan soalan ujian sebelum menyelesaikannya.

13 Saya memeriksa ketepatan jawapan saya semasa saya sedang menjalani ujian.

14 Saya mengenal pasti maklumat yang relevan dalam teks untuk membantu saya memahami teks dan menjawab soalan.

3.96 Tinggi

4.19

Tinggi

Sangat

4.23 Tinggi

Soalan 1, 'saya menterjemahkan teks bacaan dan tugasan ke dalam bahasa Rungus untuk meningkatkan pemahaman saya' memperoleh skor min 4.08. Data ini menunjukkan bahawa strategi kognitif tersebut digunakan pada tahap tinggi oleh peserta kajian dalam proses pemahaman bacaan. Soalan 2, 'saya cuba memahami teks dan soalan tanpa menghiraukan pengetahuan perbendaharaan kata saya' memperoleh skor min 4.35. Strategi kognitif ini digunakan pada tahap sangat tinggi. Soalan 3, 'saya cuba mencari topik dan idea utama petikan tanpa membaca secara terperinci' memperoleh skor min 4.23, iaitu pada tahap sangat tinggi. Soalan 4 'saya membaca teks dan soalan beberapa kali untuk lebih memahaminya' memperoleh skor min 3.69. Penulis mendapati bahawa strategi kognitif ini digunakan pada tahap tinggi. Soalan 5, 'saya menggunakan pengetahuan terdahulu untuk membantu memahami teks' memperoleh skor min 4.12. Strategi kognitif ini juga digunakan pada tahap tinggi oleh peserta kajian dalam Kumpulan Pencapaian Tinggi (KPT).

Selanjutnya, soalan 6, 'saya sedar akan apa dan bagaimana saya menjawab ujian' memperoleh skor min 4.08. Data ini menunjukkan bahawa strategi meta kognitif ini digunakan pada tahap tinggi. Soalan 7 , 'saya menyemak jawapan saya semasa sedang menjalani ujian' memperoleh skor min 4.35. Didapati bahawa strategi meta kognitif ini digunakan pada tahap sangat tinggi. Soalan 8 , 'saya membetulkan kesilapan dengan segera apabila ditemui' memperoleh skor min 4.23, iaitu digunakan pada tahap sangat tinggi. Soalan 9, 'saya menentukan apa soalan ujian kehendaki saya lakukan' memperoleh skor min 3.69. Strategi meta kognitif ini digunakan pada tahap yang tinggi. Soalan 10, 'saya sedar keperluan untuk merancang tindakan' memperoleh skor min 4.12. Strategi meta kognitif ini juga digunakan pada tahap yang tinggi. Soalan 11, 'saya cuba memahami soalan-soalan secukupnya sebelum cuba menjawabnya' memperoleh skor min 4.69. Penulis mendapati bahawa strategi meta kognitif ini digunakan pada tahap sangat tinggi. Soalan 12, 'saya sedar akan ada strategi terpilih yang dapat membantu saya untuk melengkapkan soalan ujian sebelum menyelesaikannya' memperoleh skor min 3.96, iaitu digunakan pada tahap tinggi. Soalan 13, 'saya memeriksa ketepatan jawapan saya semasa saya sedang menjalani ujian' memperoleh skor min 4.19. Data ini bermaksud strategi meta kognitif ini digunakan pada tahap tinggi. Soalan 14, 'saya mengenal pasti maklumat yang relevan dalam teks untuk membantu saya memahami teks dan menjawab soalan' memperoleh skor min 4.23. Data ini menunjukkan bahawa strategi meta kognitif ini digunakan pada tahap sangat tinggi oleh peserta kajian dalam Kumpulan Pencapaian Tinggi (KPT).

Berdasarkan min tahap penggunaan strategi kognitif pada Jadual 2, tidak ada item strategi kognitif yang memperoleh respons tahap rendah dan sederhana dalam kalangan peserta KPT. Terdapat tiga strategi kognitif pada tahap tinggi dan dua pada tahap sangat tinggi. Bagi strategi meta kognitif, tidak ada item yang memperoleh respons rendah dan sederhana. Tahap tinggi memperoleh lima respons sementara empat respons diperoleh bagi tahap sangat tinggi. Berdasarkan maklumat daripada Jadual 2, penulis 
mengetahui bahawa peserta KPT menggunakan kedua-dua strategi kognitif dan strategi meta kognitif dalam pemahaman bacaan.

Menurut tafsiran Osuji (2017: 75), strategi yang digunakan pada tahap rendah bermaksud strategi ini jarang atau hanya kadang-kadang digunakan oleh penutur asli bahasa Rungus dalam pemahaman bacaan. Strategi yang digunakan pada tahap sederhana bererti pembaca kerap menggunakan strategi tersebut. Penggunaan strategi pada tahap tinggi menunjukkan peserta biasa dengan strategi itu. Pada tahap sangat tinggi bermaksud peserta selalu menggunakan strategi itu dalam pemahaman bacaan. Kesimpulannya, peserta kajian menggunakan kedua-dua strategi pemahaman bacaan (kognitif dan meta kognitif). Akan tetapi, mereka lebih cenderung menggunakan strategi meta kognitif berbanding dengan strategi kognitif semasa mereka berusaha memahami teks bacaan dalam bahasa Melayu.

\section{Perbincangan}

Hasil kajian ini menunjukkan terdapat beberapa item strategi hampir tidak digunakan oleh murid suku kaum Rungus. Hasil analisis yang dipaparkan dalam Jadual 1 menunjukkan bahawa daripada lima item strategi kognitif dalam senarai soal selidik, item kognitif 1 ('Saya menterjemahkan teks bacaan dan tugasan ke dalam bahasa Rungus untuk meningkatkan pemahaman saya.') digunakan oleh peserta Kumpulan Pencapaian Rendah (KPR) pada tahap rendah. Hal ini bermaksud terdapat kecenderungan peserta untuk menggunakan item 1 strategi kognitif. Boleh jadi bahasa Rungus aktif dalam benak pembaca walaupun mereka berusaha membina makna dari teks bahasa Melayu. Dapatan kajian ini menyokong pernyataan Elekaei, Tabrizi \& Chalak (2020) bahawa penggunaan strategi kognitif mempermudah pembelajaran bahasa kedua dengan kaedah terjemahan bahasa pertama. Walaupun penggunaan strategi ini tidak banyak, ada peserta menterjemahkan bahasa Melayu ke dalam bahasa Rungus untuk meningkatkan pemahaman bacaan. Walaupun rendah, pemeringkatan min yang diterima bagi item menterjemahkan teks bacaan daripada bahasa Melayu kepada bahasa Rungus $(\mathrm{M}=2.14)$ menunjukkan bahawa peserta KPR kadang-kadang menggunakan strategi kognitif 1 . Hasil ini tidak memeranjatkan memandangkan bahasa Melayu bukanlah bahasa yang digunakan dalam kehidupan seharian masyarakat suku kaum Rungus di Kudat, Sabah.

Akibat langsung peranannya sebagai bahasa komunikasi yang lebih luas di Sabah, bahasa Melayu telah menjadi wahana pemikiran antara pelbagai kumpulan etnolinguistik, tidak terkecuali penutur bahasa Rungus. Ada yang berpendapat bahasa Melayu yang wujud di Sabah ialah kelainan salah satu daripada dialek Melayu di Malaysia. Oleh hal yang demikian, sebilangan peserta kadang-kadang menterjemahkan bahasa Melayu ke dalam bahasa Rungus bagi meningkatkan pemahaman dalam bahasa Melayu ialah strategi pemprosesan teks yang unik yang belum pernah dilaporkan dalam kajian tentang pembelajaran bahasa kedua di Sabah. Kajian ini turut mendapati peserta membaca teks dan soalan beberapa kali untuk lebih memahaminya pada tahap sangat tinggi $(M=4.22)$. Bagi strategi meta kognitif, KPR selalu cuba memahami soalan-soalan secukupnya sebelum cuba menjawabnya pada tahap sangat tinggi $(\mathrm{M}=4.32)$. Hasil kajian ini menyokong kajian Kutluturk \& Yumru (2017) bahawa pelajar menggunakan strategi meta kognitif untuk merancang dan memantau proses pemahaman mereka. Nilai min strategi penggunaan meta kognitif dalam pemahaman bacaan KPR lebih tinggi berbanding dengan strategi kognitif. Penemuan ini bertentangan dengan kajian Latifa (2017) yang mengatakan bahawa pelajar dapat menerapkan strategi kognitif dengan lebih baik. Tabatabaei et al. (2017) juga mengenal pasti bahawa pelajar berkemahiran tahap rendah memilih strategi kognitif.

Strategi kognitif yang selalu digunakan oleh peserta Kumpulan Pencapaian Tinggi (KPT) pada tahap sangat tinggi $(M=4.35)$ ialah item 2 , iaitu mereka cuba memahami teks dan soalan tanpa menghiraukan pengetahuan perbendaharaan kata mereka. Latifa (2017) menghubungkaitkan tindakan ini dengan pencarian maklumat yang tidak jelas, seperti meneka, bertanya kepada rakan atau guru dan menggunakan kamus. Pada masa yang sama, strategi meta kognitif yang selalu digunakan KPT sama sekali bertentangan dengan strategi kognitif item 2. Strategi meta kognitif item 11 ('Saya cuba memahami soalan-soalan secukupnya sebelum cuba menjawabnya.') mendapat respons sangat tinggi ( $\mathrm{Min}=4.69)$. Hasil kajian ini selaras dengan kajian Tabatabaei et al. (2017) bahawa pelajar yang berjaya ialah pelajar yang memantau kemahiran belajar mereka melalui penggunaan strategi meta kognitif. Terdapat 
hubungan positif yang signifikan antara kesedaran meta kognitif dan prestasi pelajar berkemahiran tahap tinggi. Penemuan ini tidak sejajar dengan kajian Ahmed (2020) yang mengatakan bahawa para peserta mempunyai kesedaran menggunakan strategi kognitif lebih kerap daripada strategi meta kognitif. Demikian juga halnya dengan kajian Commander et al. (2016), iaitu pelajar paling menyukai kategori strategi kognitif.

Sebagai rumusan, hasil kajian ini menunjukkan bahawa kedua-dua peserta kumpulan (KPT dan KPR) lebih kerap menggunakan strategi meta kognitif daripada strategi kognitif dalam pemahaman bacaan teks bahasa Melayu. Secara langsung, implikasi kajian ini telah menjawab persoalan kajian yang dikemukakan oleh penulis, iaitu strategi meta kognitif mengatasi strategi kognitif. Strategi kognitif digunakan untuk menggiatkan proses kognitif seperti menggaris beberapa bahagian teks, membaca kembali sebahagian atau seluruh teks untuk meningkatkan pemahaman, atau mengurangkan kecepatan membaca bila pemahaman terganggu (Sheorey \& Mokhtari 2001). Konsep strategi meta kognitif melibatkan usaha merancang, memantau dan menilai proses pembelajaran sesuatu tugasan (Phakiti 2003).

\section{Implikasi}

Penulis melaksanakan kajian ini khusus untuk memberi kesedaran tentang fungsi strategi kognitif dan meta kognitif yang signifikan dalam pemahaman bacaan, terutama bagi guru bahasa yang masih meneruskan kaedah pengajaran tradisional di dalam kelas. Hasil kajian yang dilaporkan dalam makalah ini mempunyai beberapa implikasi positif terhadap pengajaran membaca dalam bahasa kedua, khususnya mata pelajaran Bahasa Melayu di sekolah-sekolah di kawasan pedalaman Sabah. Strategi kognitif dan meta kognitif memainkan peranan dalam meningkatkan prestasi pemahaman bacaan di dalam kelas. Berdasarkan pengalaman sebagai seorang guru, seringkali guru bahasa dalam kelas bahasa kedua tidak jelas mengapa sebilangan murid sukar memahami teks yang dibaca. Sebagai akibatnya, guru bahasa berhadapan dengan pengalaman menjengkelkan kerana murid tampak memahami setiap ayat yang dibaca tetapi tidak dapat menjawab soalan yang mudah tentang teks atau petikan yang telah dibaca. Sehubungan dengan itu, data kajian ini berguna kepada para guru yang sering kali berada dalam situasi yang sedemikian sukar.

Murid-murid dapat dibantu untuk memahami teks bertulis dengan lebih baik sekiranya mereka diberi petunjuk cara menggunakan strategi kognitif dan strategi meta kognitif semasa membaca teks atau petikan. Beberapa kajian terdahulu (misalnya, Osuji 2017; Elekaei et al. 2020) menunjukkan bahawa penggunaan kedua-dua strategi tersebut memudahkan pembelajaran juga meningkatkan prestasi murid dalam tugas pemahaman bacaan. Oleh itu, guru bahasa kedua di Sabah dapat mengurangkan kaedah pengajaran membaca secara tradisional sebaliknya menggunakan strategi sebagai pendekatan pragmatik dalam pengajaran membaca. Penggunaan strategi pemahaman bacaan yang salah memberi kesan terhadap prestasi murid dalam tugas membina makna dari teks yang ditulis dalam bahasa kedua. Guru boleh menyesuaikan konstruk strategi membaca dengan kaedah tertentu agar memudahkan murid memproses pemahaman bacaan teks dalam bahasa kedua. Strategi kognitif dan meta kognitif ialah sumber yang masih kurang dimanfaatkan dalam sistem pendidikan di Sabah.

\section{Kesimpulan}

Kebanyakan penutur asli suku kaum Rungus menggunakan bahasa Melayu sebagai bahasa kedua. Hakikatnya, bagi mereka pemahaman bacaan teks bahasa Melayu ialah satu cabaran. Peserta kajian tiada pilihan dan perlu belajar bahasa Melayu secara formal di sekolah kerana bahasa tersebut merupakan bahasa pengantar utama dalam sistem pendidikan di Malaysia. Kajian ini bertujuan untuk menentukan penggunaan strategi kognitif dan meta kognitif dalam pemahaman bacaan teks bahasa Melayu oleh para peserta dan memastikan sumbangan kedua-dua strategi dalam pemahaman bacaan. Hasil kajian ini mendapati bahawa peserta menggunakan lima item strategi kognitif dan 9 item strategi meta kognitif dalam pemahaman bacaan. Tahap penggunaan strategi ini adalah berbeza-beza. Walaupun demikian, strategi pemahaman bacaan peserta pada kekerapan penggunaannya tampak memberi kesan positif 
terhadap pemahaman bacaan mereka. Walaupun penggunaan dua daripada 14 item strategi yang dilaporkan dalam pemahaman bacaan berada pada tahap penggunaan sederhana, secara keseluruhannya strategi kognitif dan strategi meta kognitif telah menyumbang pada pemahaman bacaan yang lebih baik bagi kedua-dua peserta kumpulan.

\section{Rujukan}

Abbott, M. L. (2006). ESL reading strategies: Differences in Arabic and Mandarin speaker test performance. Language Learning, 56(4), 633-670.

Ahmed, R. M. (2020). Investigating EFL Learners' Awareness of Cognitive and Metacognitive Reading Strategies of Students in Different Disciplines. Arab World English Journal, 11(3), 294-304.

Ashton-Hay, S., \& Brookes, D. (2011). Here's a story: Using student podcasts to raise awareness of language learning strategies. EA Journal, 26(2), 15-27.

Bimmel, P. E., van den Bergh, H., \& Oostdam, R. J. (2001). Effects of strategy training on reading comprehension in first and foreign language. European Journal of Psychology of Education, 16(4), 509-529.

Carifio, L., \& Perla, R. (2008). Resolving the 50 year debate around using and misusing Likert scales. Medical Education, 42(12), 1150-1152.

Commander, N. E., Ashong, C., \& Zhao, Y. (2016). Metacognitive Awareness of Reading Strategiesby Undergraduate US and Chinese Students. Journal of College Literacy and Learning, 42, 40.

Elekaei, A., Tabrizi, H. H., \& Chalak, A. (2020). A Study into the Impact of the Choice of Cognitive and Meta-Cognitive Strategies and Podcasts on Vocabulary Gain and Retention Levels in the" Telegram"-Based E-Learning Context. Teaching English with Technology, 20(2), 98-117.

Kern, R. G. (1989). Second language reading strategy instruction: Its effects on comprehension and word inference ability. The Modern Language Journal, 73, 135-149.

Koda, K. (2007). Reading and language learning: Cross-linguistic constraints on second language reading development. Language Learning, 57(1), 1-44.

Kutluturk, S., \& Yumru, H. (2017). Cognitive and Metacognitive Strategy Training to Enhance Freshmen's Reading Skills. International Journal of Language and Literature, 5(1), 7-15.

Latifa, I. S. (2016, November). A Description of The Uses of Metacognitive Self Regulation and Cognitive Strategy Used with Reading Comprehension. In Ninth International Conference on Applied Linguistics (CONAPLIN 9). Atlantis Press.

Macaro, E. (2006). Strategies for Language Learning and for Language Use: Revising the Theoretical Framework. The Modern Language Journal, 90, 320-337. 10.1111/j.1540-4781 .2006.00425.x.

Maftoon, P. \& Tasnimi, M. (2014). Using self-regulated to enhance EFL learners' reading comprehension. Journal of Language Teaching and Research, 5(4), 844-855.

McNeil, L. (2011). Investigating the contributions of background knowledge and reading comprehension strategies to L2 reading comprehension: An explanatory study. Read Writ, 24 (8), 883-902.

Norman, G. (2010). Likert scales, levels of measurement and the "laws" of statistics. Advanced Health Science Education Theory Practice, 15(5), 626-632.

Osuji, C. J. (2017). Cognitive and metacognitive strategy use in first and second language reading comprehension. PhD Thesis. University of Essex, United Kingdom.

Oxford, R. (2011). Teaching and researching language learning strategies. Harlow, United Kingdom: Pearson Education.

Phakiti, A. (2006). Modeling cognitive and metacognitive strategies and their relationships to EFL reading test performance. Melbourne Papers in Language Testing, 1, 53-95.

Sheorey, R., \& Mokhtari, K. (2001). Differences in the metacognitive awareness of reading strategies among native and non-native readers. System, 29(4), 431- 449.

Tabatabaei, S. S., Ahadi, H., Bahrami, H., \& Khamesan, A. (2017). The effects of motivated strategies for learning questionnaire (MSLQ) on students' cognitive and meta-cognitive skills. NeuroQuantology, 15(2): 239-245.

Williams, M., Mercer, S., \& Ryan, S. (2015). Oxford handbooks for language teachers: Exploring psychology in language learning and teaching. United Kingdom: Oxford University Press.

Yau, J.-1. C. (2009). Reading characteristics of Chinese-English adolescents: Knowledge and application of strategic reading. Metacognition and Learning, 4(3), 217-235. 
DOI: https://doi.org/10.47405/mjssh.v5i12.579

Zarei, A. A., \& Elekaei, A. (2012). Learner Autonomy and Language Learning Strategies: An Empirical Analysis. Riga, Latvia: Lambert Academic Publishing.

Zhang, L. J., \& Wu, A. (2009). Chinese senior high school EFL students' metacognitive awareness and reading-strategy use. Reading in a Foreign Language, 21(1), 37-59. 